\title{
Axial myoclonus after ischemic stroke
}

回

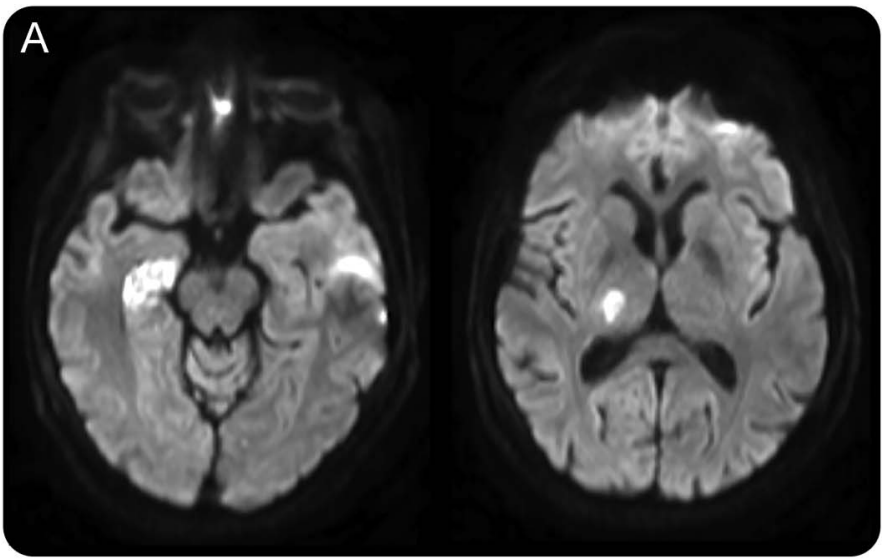

B

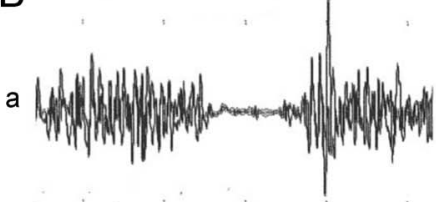

$\longmapsto 160 \mathrm{~ms}$

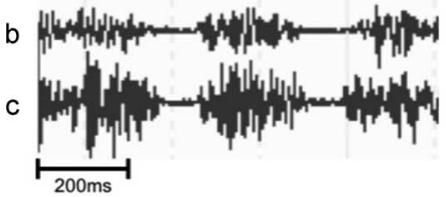

(A) MRI diffusion-weighted images show the ischemic areas. (B) EMG of left deltoid (a), right D5 paraspinal (b) and left D5 paraspinal dorsal muscles (c) show periods of muscular atonia.

Myoclonus is an unusual manifestation of stroke. ${ }^{1}$ We report a 67-year-old woman admitted with an acute ischemic stroke in the right thalamo-capsular and hippocampal areas (figure). Becoming upright produced marked postural instability, due to an apparent reduction in cervical and dorsal axial muscle tone. EMG disclosed negative myoclonus in left upper limb and right paraspinal muscles, and both negative and positive myoclonus in left paraspinal muscles (video on the Neurology ${ }^{\circledR}$ Web site at Neurology.org). No epileptic activity was observed on EEG.

Axial negative myoclonus is a rare phenomenon, mostly described in posthypoxic and certain epileptic syndromes, ${ }^{2}$ but is a novel occurrence in stroke.

Pedro Nascimento Alves, MD, Mamede de Carvalho, PhD, Rita Peralta, MD, Ruth Geraldes, MD,

Ana Catarina Fonseca, PhD, Teresa Pinho e Melo, MD

From the Department of Neurology, Hospital de Santa Maria, Lisbon, Portugal.

Author contributions: P.N. Alves: drafting the manuscript for content, including medical writing for content; study concept or design; interpretation of data. M. de Carvalho: revising the manuscript for content, including medical writing for content; study concept or design; interpretation of data. R. Peralta: revising the manuscript for content, including medical writing for content; study concept or design; interpretation of data. R. Geraldes: revising the manuscript for content, including medical writing for content; study concept or design; interpretation of data. A.C. Fonseca: revising the manuscript for content, including medical writing for content; study concept or design; interpretation of data. T. Pinho e Melo: revising the manuscript for content, including medical writing for content; study concept or design; interpretation of data.

Study funding: No targeted funding reported.

Disclosure: The authors report no disclosures relevant to the manuscript. Go to Neurology.org for full disclosures.

Supplemental data at Neurology.org
Correspondence to Dr. Alves: pedronascimentoalves@gmail.com

1. Mehanna R, Jankovic J. Movement disorders in cerebrovascular disease. Lancet Neurol 2013;12:597-608.

2. Rubboli G, Tassinari CA. Negative myoclonus: an overview of its clinical features, pathophysiological mechanisms, and management. Neurophysiol Clin 2006;36:337-343. 


\title{
Neurology
}

\author{
Axial myoclonus after ischemic stroke \\ Pedro Nascimento Alves, Mamede de Carvalho, Rita Peralta, et al. \\ Neurology 2015;85;654 \\ DOI 10.1212/WNL.0000000000001858
}

This information is current as of August 17, 2015

\begin{tabular}{|c|c|}
\hline $\begin{array}{l}\text { Updated Information \& } \\
\text { Services }\end{array}$ & $\begin{array}{l}\text { including high resolution figures, can be found at: } \\
\text { http://n.neurology.org/content/85/7/654.full }\end{array}$ \\
\hline Supplementary Material & $\begin{array}{l}\text { Supplementary material can be found at: } \\
\text { http://n.neurology.org/content/suppl/2015/08/15/WNL.0000000000001 } \\
\text { 858.DC1 }\end{array}$ \\
\hline References & $\begin{array}{l}\text { This article cites } 2 \text { articles, } 0 \text { of which you can access for free at: } \\
\text { http://n.neurology.org/content/85/7/654.full\#ref-list- } 1\end{array}$ \\
\hline Subspecialty Collections & $\begin{array}{l}\text { This article, along with others on similar topics, appears in the } \\
\text { following collection(s): } \\
\text { Clinical neurology examination } \\
\text { http://n.neurology.org/cgi/collection/clinical_neurology_examination } \\
\text { EMG } \\
\text { http://n.neurology.org/cgi/collection/emg } \\
\text { Infarction } \\
\text { http://n.neurology.org/cgi/collection/infarction } \\
\text { Myoclonus } \\
\text { http://n.neurology.org/cgi/collection/myoclonus }\end{array}$ \\
\hline Permissions \& Licensing & $\begin{array}{l}\text { Information about reproducing this article in parts (figures,tables) or in } \\
\text { its entirety can be found online at: } \\
\text { http://www.neurology.org/about/about_the_journal\#permissions }\end{array}$ \\
\hline Reprints & $\begin{array}{l}\text { Information about ordering reprints can be found online: } \\
\mathrm{http} / / / \mathrm{n} \text {.neurology.org/subscribers/advertise }\end{array}$ \\
\hline
\end{tabular}

Neurology ${ }^{\circledR}$ is the official journal of the American Academy of Neurology. Published continuously since 1951, it is now a weekly with 48 issues per year. Copyright (C 2015 American Academy of Neurology. All rights reserved. Print ISSN: 0028-3878. Online ISSN: 1526-632X.

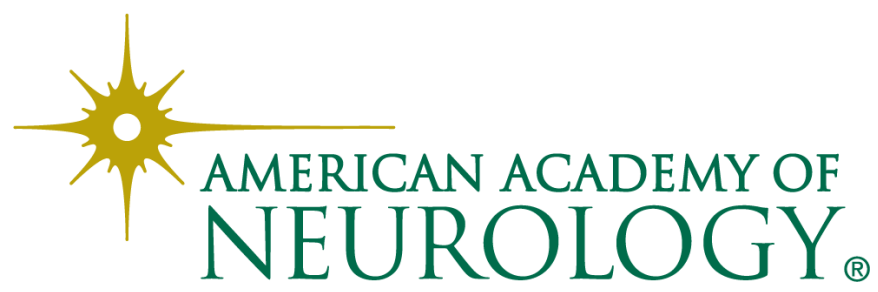

